\title{
Pemanfaatan Daun Kelampan Sebagai Biopestisida Dalam Penanggulangan Hama Pada Tanaman Cabai
}

\author{
Dian Aristina \\ SMAN 1 Kota Besi, Jalan Tengku Gembo Kota Besi Hilir Kecamatan Kota Besi, \\ Kabupaten Kotawaringin Timur, Kalimantan Tengah, Indonesia \\ email: dian4741@gmail.com
}

\begin{abstract}
Abstrak. Kelampan (Cerbera odollam) adalah tanaman yang banyak dijumpai disekitar kita sebagai tanaman penghijauan atau tanaman peneduh. Tanaman Kelampan mengandung senyawa golongan alkaloid yang bersifat racun,yaitu cerberin. Cerberin merupakan racun yang sangat berpengaruh terhadap mortalitas pada serangga. Tanaman cabai termasuk dalam tanaman favorit para petani yang menjanjikan keuntungan dengan harganya yang sering melambung tinggi. Namun serangan hama ulat sering menggangu para petani untuk dapat menghasilkan cabai yang diinginkan. Oleh karena itulah dilakukan penelitian untuk memanfaatkan daun Kelampan sebagai biopestisida dalam penanggulangan hama ulat pada tanaman cabai. Penelitian ini dilakukan secara eksperimen di kebun sayur milik salah satu warga di Kec.Kota Besi. Bagian tanaman Kelampan yang digunakan sebagai biopestisida adalah daunnya baik daun kering dan daun basah. Penelitian dilakukan dengan menyemprotkan ekstrak daun kelampan dengan beberapa varian konsentrasi $100 \mathrm{~mL} / \mathrm{L}(\mathrm{v} / \mathrm{v}), 200 \mathrm{~mL} / \mathrm{L}(\mathrm{v} / \mathrm{v}), 300 \mathrm{~mL} / \mathrm{L}(\mathrm{v} / \mathrm{v})$ dan $400 \mathrm{~mL} / \mathrm{L}(\mathrm{v} / \mathrm{v})$ pada tanaman cabai yang berumur 15 hari. Pembuatan ekstrak daun kelampan menggunakan bahan yang sederhana sehingga para petani bisa mengaplikasikannya dengan mudah. Hasil penelitian menunjukkan bahwa pemberian ekstrak daun kelampan berpengaruh secara signifikan terhadap mortalitas ulat grayak yang dilihat dari jumlah daun berlubang pada tanaman cabai. Diperlukan penelitian lebih lanjut untuk menyempurnakan hasil penelitian ini.
\end{abstract}

Kata kunci: daun, biopestisida, cabai, kelampan

\section{PENDAHULUAN}

Kelampan (Cerbera odollam) atau dikenal juga dengan nama Bintaro adalah tanaman yang banyak dijumpai disekitar kita dan dikenal sebagai tanaman peneduh atau tanaman penghijauan yang biasa ditanam di pekarangan rumah, taman-taman dan banyak juga di pinggiran jalan. Tanaman ini merupakan salah satu jenis tanaman famili Apocynaceae. Tanaman ini menrupakan jenis tanaman dengan ketinggian dapat mencapai $20 \mathrm{~m}$, batang tegak, bulat berkayu dengan bintik-bintik hitam. Daun tunggal tersebar agak lonjong, tepi rata dan ujung dan pangkal meruncing bertulang menyirip tipis dan licin (S. Asikin, 2013).

Hampir seluruh bagian tanaman Kelampan bersifat racun, karena mengandung senyawa alkaloid yang disebut "cerberin". Cerberin adalah racun 
yang dapat mengganggu fungsi saluran ion calsium dalam otot jantung, sehingga menggangu detak jantung dan dapat menyebabkan kematian (Tomlinson, 1986, dalam Kartimi, 2015). Walaupun termasuk tanaman beracun, Kelampan memiliki banyak manfaat untuk kepentingan manusia, seperti sebagai pembasmi tikus (meletakan buahnya di sarang tikus), bahan baku lilin, biopestisida, obat luka, deodorant, dan minyak biji kelampan.bintaro berpotensi sebagai biodiesel (Arurasameru. 2011).

Tanaman Cabai adalah salah satu komoditi utama yang memiliki nilai ekonomis yang tinggi. Mahalnya harga cabai menjadi pemicu keinginan para petani untuk menanam tanaman tersebut. Tanaman ini memberikan keuntungan yang sangat menjanjikan bagi para petani. Namun serangan hama ulat sering menggangu tanaman cabai sehingga petani tidak dapat menghasilkan produksi seperti yang diinginkan. Ulat grayak (Spodoptera litura Fabricus) merupakan salah satu hama pengganggu tanaman cabai. Ulat ini menyerang daun muda atau daun tua sehingga daun menjadi berlubang dan bentuknya tidak beratutan. Untuk mengendalikan hama tersebut, petani pada umunya lebih suka mengaplikasikan pestisida. Hal ini dikarenakan pestisida dianggap sangat efektif dan praktis serta cepat dalam membunuh hama pada tanaman. Penggunaan pestisida terutama pestisida sintetis telah berhasil menyelamatkan hasil pertanian yang dihancurkan oleh jasad pengganggu, namun menimbulkan dampak negatif terhadap alam, lingkungan maupu manusia (Sastroutomo, 1982, dalam Kartimi, 2015). Dampak negatif penggunaan peptisida diantaranya adalah resistensi hama terhadap pestisida dan juga pengeluaran yang terlalu besar bagi petani untuk pembelian pestisida tersebut.

Biopestisida adalah bahan yang berasal dari alam, seperti tumbuh-tumbuhan yang digunakan untuk mengendalikan organisme pengganggu tanaman atau juga disebut pestisida hayati. Biopestisida ini merupakan salah satu solusi ramah lingkungan dalam rangka menekan dampak negatif penggunaan pestisida sintetis. Kelampan merupakan salah satu tanaman yang dapat digunakan sebagai biopestisida. Oleh karena itu, pemanfaatan tanaman kelampan sebagai biopeptisida diharapkan dapat menjadi alternatif pengendalian hama ulat grayak pada tanaman cabai.

\section{METODE PENELITIAN}

Penelitian ini dilakukan di salah satu kebun tanaman cabai milik bapak Saiful Bahri di kecamatan Kota Besi pada bulan Oktober 2017. Bahan yang digunakan adalah daun kelampan, air, sabun colek, dan tanaman cabai yang berumur 15 hari. Alat yang digunakan adalah blender, timbangan, saringan, gelas ukur, corong, hand sprayer, botol plastik. Dipilih alat dan bahan yang sederhana sehingga petani dapat dengan mudah mengaplikasikannya.

Pembuatan ekstrak daun Kelampan dengan cara menghaluskan 50 gram daun kelampan yang telah dicuci dan dikering-anginkan dengan 2 gram sabun colek dalam 1 liter air, hasilnya disaring dan diperas sehingga menghasilkan larutan yang sedikit kental.

Pengaplikasian ekstrak daun Kelampan dengan cara menyemprotkan ekstrak daun kelampan pada tanaman cabai yang berumur 15 hari dengan varian konsentrasi yaitu $100 \mathrm{~mL} / \mathrm{L}(\mathrm{v} / \mathrm{v}), 200 \mathrm{~mL} / \mathrm{L}(\mathrm{v} / \mathrm{v}), 300 \mathrm{~mL} / \mathrm{L}(\mathrm{v} / \mathrm{v})$ dan $400 \mathrm{~mL} / \mathrm{L}$ $(\mathrm{v} / \mathrm{v})$. Penyemprotan dan pengamatan daun tanaman cabai dilakukan pada sore 
hari selama 10 hari dengan melihat jumlah daun berlubang yang dimakan oleh ulat grayak pada tanaman cabai. Sebagai kontrol digunakan air atau tanpa penggunaan ekstrak daun Kelampan.

\section{HASIL PENELITIAN DAN PEMBAHASAN}

Pada awal penelitian, jumlah daun yang terdapat pada tanaman cabai adalah 4 lembar dan belum terdapat lubang-lubang akibat dimakan oleh ulat grayak. Dari hasil penelitian yang dilakukan, diperoleh data sebagai berikut :

\section{Tabel 1. Hasil pengamatan pada daun berlubang}

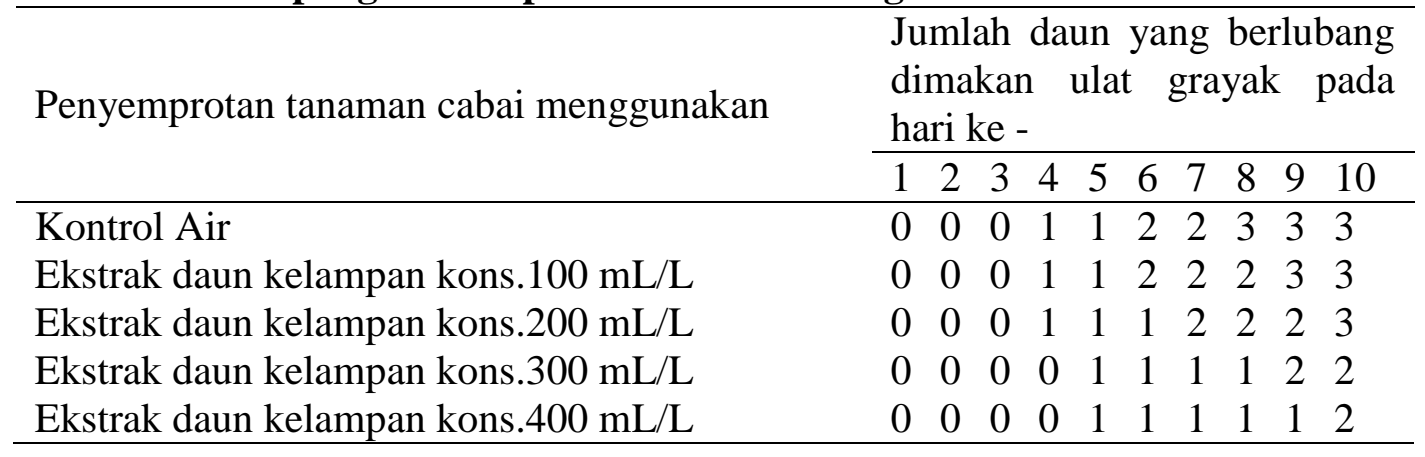

Berdasarkan hasil penelitian di atas, didapatkan hasil bahwa penggunaan ekstrak daun kelampan memberikan pengaruh terhadap mortalitas hama ulat grayak pada tanaman cabai yang dapat dilihat dari jumlah daun berlubang. Pada pemberian ekstrak daun kelampan dengan konsentrasi $100 \mathrm{~mL} / \mathrm{L}$ hanya menunjukkan sedikit penurunan jumlah daun yang berlubang pada tanaman cabai. Pada pemberian ekstrak daun kelampan dengan konsentrasi $200 \mathrm{~mL} / \mathrm{L}$ mulai menunjukkan peningkatan penurunan jumlah daun yang berlubang pada tanaman cabai. Demikian pula untuk pemberian ekstrak daun kelampan dengan konsentrasi $300 \mathrm{~mL} / \mathrm{L}$. Pemberian ekstrak daun kelampan dengan konsentrasi $400 \mathrm{~mL} / \mathrm{L}$ menunjukkan hasil yang paling signifikan dalam penurunan jumlah daun yang berlubang pada tanaman cabai.

Penurunan jumlah daun yang berlubang pada tanaman cabai menunjukkan hubungan dengan penurunan jumlah ulat grayak yang memakan daun tanaman cabai tersebut. Semakin kecil jumlah daun yang berlubang pada tanaman cabai semakin kecil jumlah.



Gambar 1. Grafik hubungan jumlah lubang pada daun terhadap waktu (hari) 


\section{SIMPULAN}

Berdasarkan hasil yang didapat pada penelitian ini, pengaplikasian ekstrak daun Kelampan pada tanaman cabai dapat mengurangi jumlah lubang pada daun tanaman cabai akibat dimakan oleh ulat grayak. Ekstrak daun kelampan dengan konsentrasi $400 \mathrm{~mL} / \mathrm{L}$ (v/v) menunjukkan jumlah daun berlubang yang terdapat pada tanaman cabai. Penurunan jumlah daun yang berlubang pada tanaman cabai menunjukkan hubungan dengan penurunan jumlah ulat grayak yang memakan daun tanaman cabai tersebut. Semakin kecil jumlah daun yang berlubang pada tanaman cabai semakin kecil jumlah.

\section{DAFTAR RUJUKAN}

Sa'diyah N.A., Purwanti K.I., \&Wijayawati L.(2013).Pengaruh ekstrak daun bintaro (Cerbera odollam) terhadap perkembangan ulat grayak (Spodoptera litura F.). Jurnal Sains dan Seni Pomits Vol.2 No.2.

Kartimi.(2015).Pemanfaatan buah bintaro sebagai biopestisida dalam penanggulangan hama pada tanaman padi di kawasan pesisir desa Bandengan kabupaten Cirebon.Prosiding Seminar Nasional Pendidikan Biologi 2015 yang diselenggarakan oleh Prodi Pendidikan Biologi FKIP Universitas Muhammadiyah Malang, tema: "Peran Biologi dan Pendidikan Biologi dalam Menyiapkan Generasi Unggul dan Berdaya Saing Global”.

Rio Pratama.(2014).Pengaruh campuran ekstrak bintaro (Cerbera manghas) dan EM4 (Effective Microorganism 4) pada perkembangan tanaman cabai besar (Capsicum annum L.).Karya Ilmiah Program Studi Managemen Lingkungan.Politeknik Pertanian Negeri Samarinda.

Julianti, Mardhiansyah M., Arlita T.(2016). Uji beberapa konsentrasi ekstrak daun bintaro (Cerbera manghas L.) sebagai pestisida nabati untuk mengendalikan hama ulat jengkal (Plusia sp.) pada trembesi (Samanea saman (Jarq.)Merr). Jom Faperta Universitas Riau Vol 3 No 1 Februari 2016. 